\title{
Cemitérios verticais, espaço urbano e meio ambiente: 0 novo discurso científico universitário de incentivo à verticalização do cemitério e à cremação
}

\begin{abstract}
Barbara Thompsom*
Resumo: Este estudo visa à análise do discurso científico que, nos últimos tempos, vem difundindo e incentivando a implantação de cemintérios verticais e de crematórios no Brasil. Entre 2000 e 2014, diversos artigos acadêmicos abordaram a contaminação das águas subterrâneas devido ao necrochorume produzido pela decomposição dos corpos. Assim, esta análise se apresenta como uma ponderação favorável à reestruturação dos cemitérios, enquanto parte da solução do problema de degradação ambiental. De antemão, faz-se necessário esclarecer a inviabilidade de conclusões categóricas, dada a atualidade do estudo - ainda em andamento. Visa-se, então, a fim de corroborar para a literatura específica de um estudo tão recente, a comparação entre o discurso higienista dos séculos XVIII e XIX, e o discurso científico hodierno da sustentabilidade ambiental. A relevância dessa comparação reside na configuração do espaço urbano, que leva em conta a forma como a sociedade concebe a morte. 0 discurso mais antigo, por exemplo, foi responsável pelo afastamento dos cemitérios da Igreja Católica em relação à cidade. No atual contexto, por outro lado, a verticalização dos cemitérios é cientificamenete favorecida pelo fator meio ambiente. Tais investigações convergem para um desenredo que, embora aponte para valorização da sustentabilidade, apresenta-se ainda dicotômico: a defesa do meio ambiente é tão válida quanto necessária, todavia consiste num discurso científico que oculta a negação da morte, presente em nossa sociedade. 0 cemitério vertical extingue símbolos que promovem a memória dos mortos e dos grupos. Com a decadência do objeto material da memória, isto é, do túmulo monumental, os grupos que se relacionam com essa memória poderão ser enfraquecidos.
\end{abstract}

Palavras-chave: discurso científico, cemitérios verticais, espaço urbano, contaminação por necrochorume, impacto ambiental.

Este artigo tem como objeto de estudo a recente produção de um discurso científico, que, enquanto potencialidade, apresenta-se favorável à instauração de cemitérios verticais e crematórios em território nacional. Há indícios desse incentivo à construção de cemitérios verticais, porém tratam-se apenas de possíveis apontamentos. As universidades brasileiras, nos últimos quatorze anos (2000-2014), desenvolveram de forma crescente monografias, teses, dissertações e trabalhos que abordam os problemas ambientais ocasionados pela estrutura do cemitério tradicional. Ressalta-se que o termo "tradicional" refere-se aos cemitérios com túmulos e monumentos para um morto que tem seu corpo enterrado no subsolo.

As precárias instalações dos cemitérios tradicionais culminam na vasão do necrochorume ao solo, contaminando os lençóis freáticos. Por "necrochorume" entende-se os líquidos provenientes da decomposição de cadáveres que, inicialmente gasosos (também chamados de efluentes cadavéricos), tornam-se, por fim, líquidos: "líquido funerário de cor acinzentada e acastanhada, com cheiro acre e fétido, mais viscoso que a água." (LEITE, 2009, p. 06). Uma vez descoberto o prejuízo ambiental causado pela configuração dos cemitérios tradicionais, instaurou-se um novo discurso acadêmico, voltado à necessidade de verticalização das necrópoles. Essa nova *Graduada em Ciências Sociais - UFES 
estruturação - em prédios - não apenas sanaria os impactos ambientais causados pelo necrochorume, como otimizaria os espaços urbanos. Soma-se a esses argumentos o fato comum a todos os treze trabalhos acadêmicos analisados que deram azo a este estudo: o de que o cemitério tradicional já não consegue dar conta das demandas por espaço, problema que só deverá se agravar com o crescimento populacional. Mais adiante, ainda neste estudo, analisar-se-ão tais argumentos de forma mais incisiva.

Segundo Ariès (1977), o espaço destinado aos mortos sofre constantes mudanças ao longo dos tempos. Na Idade Média, os cemitérios ficavam próximos às igrejas, de modo que não causavam estranhamento, mas, ao contrário, faziam parte da rotina das pessoas. Eram espaços de socialização. Posteriormente, já nos séculos XVIII e XIX, os cemitérios passaram a ser construídos longe das cidades e das habitações humanas. A partir desse ponto, instaura-se o cemitério do tipo monumental. Na contemporaneidade, os cemitérios-parques ganham destaque e apontam para a elaboração de cemitérios cada vez mais secularizados, onde não se encontram resquícios de símbolos religiosos.

Buscando compreender os fenômenos sociais da atualidade que modificam a estética e a organização do espaço destinado aos mortos, surgem algumas indagações. 0 questionamento inicial se refere aos seguintes pontos: os trabalhos acadêmicos de fato incentivam a construção de cemitérios verticais e a cremação? Se sim, é pertinente indagar por que ocorre esse processo? A universidade reflete um comportamento social já incipiente? Ou um outro caso se configura, e a universidade é autora inicial e primária de uma mudança? Partindo-se deste último pressuposto, os professores e alunos universitários utilizariam seus meios (no caso, estudos empíricos e cientificamente provados) para justificar e persuadir a população quanto às mudança na estruturação espacial e simbólica do cemitério. Assim, é relevante questionar se há e de que maneira se processa a relação entre produção acadêmica e mudanças sociais.

Outra problemática relevante trata de investigar se é válida a comparação entre o novo argumento do século XXI em prol da verticalizaão dos cemitérios - que apresenta uma nova, mais ampla e exigente noção higienista, sanitarista e ambiental - e o discurso higienista, difundido pelos médicos dos séculos XVIII e XIX em defesa da saúde, que exigia o afastamento dos cemitérios da cidade.

A escolha do objeto de estudo decorre da relevância de se averiguar o prestígio social e a influência econômica dos estudos produzidos cientificamente pelas universidades. A importância deste artigo revela-se na ponderação e na análise do poder de propagação e da (possível super) valorização do discurso científico, aptos 
tanto a apontar mudanças nos espaços urbanos, quanto a gerar e operar tais mudanças. Ademais, o estudo desse discurso permite entender os processos sociais e a modificação na forma de conceber a morte e de lidar com o corpo morto. Novos valores sociais sobre a morte são solidificados e expressos no cemitério, logo um estudo desse espaço levanta dados relevantes para o conhecimento da configuração desse processo na sociedade, seja no que diz respeito à relação desta com o fato/ figura da morte, seja no que concerne aos meios e instrumentos adotados para validar e justificar a modificação desses espaços. Por fim, soma-se ainda à relevância deste estudo a visualização da decadência dos símbolos e dos espaços que evocam a memória de um grupo. Neste caso, em particular, a memória é exercida por meio dos monumentos funerários. Se o objeto material da memória desaparece gradativamente, a lembrança aos mortos é também enfraquecida.

Num primeiro momento, investigar-se-á a elaboração das pesquisas acadêmicas sobre a verticalização de cemitérios e o ato da cremação. Pretende-se, com isso, entender como e por que tais pesquisas têm buscado a modificação da estrutura urbana vigente em diversos estados brasileiros, bem como ponderar a validade/ legitimidade de seus argumentos - a exemplo do argumento da defesa do meio ambiente. Para tanto, serão analisados treze trabalhos acadêmicos produzidos a partir do ano 2000 em universidades e faculdades do território brasileiro. Os cursos que apresentam a verticalização dos cemitérios como temática de estudo estão presentes, em sua maioria, nas áreas de Arquitetura e Urbanismo, Biologia, Geografia, na Especialização em Gestão Ambiental, no Mestrado em Desenvolvimento e Meio Ambiente, e de Geofísica.

De modo mais específico, objetiva-se descrever os processos de desenvolvimento e as conclusões a que chegam cada um desses treze trabalhos acadêmicos. Posteriormente, realizar-se-á uma comparação das ideias defendidas pelos mesmos. Finalmente, serão analisados e ponderados os argumentos-base que justificariam a verticalização dos cemitérios proposta por quase todos os treze trabalhos.

A metodologia escolhida tem abordagem qualitativa. Por meio dessa metodologia, serão estudadas as ações sociais de grupos e os desdobramentos dessas ações que geram processos de mudança nos espaços em que se vive. 0 estudo será de cunho descritivo e interpretativo, de modo a relatar e analisar a construção do discurso científico nas universidades e os dados que suportam tal discurso. Para o procedimento de pesquisa, usar-se-á o levantamento bibliográfico. 


\section{Religiosidade, secularização e cemitério: a valorização do discurso técnico- científico}

Os cemitérios inaugurados em meados do século XIX, repletos de monumentos funerários e túmulos suntuosos, representam o início de um longo processo de secularização. Na Europa, os cemitérios, a partir do século XVIII, sofreram um afastamento físico das igrejas e das cidades, devido a questões higienistas, uma vez que, sob o ponto de vista da saúde, não era aceitável viver próximo aos mortos. Além disso, as instituições religiosas perderam o controle sobre os túmulos. Mesmo nesse contexto, o espaço dos mortos permanecia como uma extensão simbólica da Igreja Católica, da religiosidade e dos valores transcendentais. Houve, ainda em meados do século XVIII, um discurso higienista que promovia a ideia de que os cemitérios eram disseminadores de graves epidemias. Mas a veracidade dessas ideias sanitaristas não foi suficiente para promover uma ruptura entre a morte e a religiosidade.

Ao final do século XX, os cemitérios de tipo parque ganharam espaço entre os vivos. Os símbolos religiosos são, então, retirados e os túmulos suntuosos também perdem lugar. $\mathrm{O}$ espaço destinado aos mortos torna-se secular à medida que a morte passa a caracterizar uma completa finitude, e desvincula-se das explicações de pósvida e continuidade do homem. 0 cemitério torna-se, assim, um parque, um jardim, algo secualirzado, lugar de neutralidade. Já no século XXI, os cemitérios verticais iniciam um tímido crescimento. Nesse ponto, a morte é mais intensamente laicizada, e sua relação com a religião sofre um enfraquecimento significativo. 0 esgarçamento dessa relação é apontado em recentes trabalhos e pesquisas antropológicas, a exemplo de Rodrigues (1983). Ao morto, agora, resta o esquecimento de sua alma. Esse processo de secularização mais intensa pode ser questionado e melhor analisado por meio de uma pesquisa de campo mais avançada. Autores como Rodrigues (1983) e Ariès (1977) abordam o tema de maneira mais aprofundada.

0 primeiro trabalho analisado foi o Relatório de Impacto Ambiental-RIMA, produzido pela empresa "Engenharia Ambiental- ECOBR," a pedido da Igreja Espiritualista Universal. 0 relatório tem por finalidade apresentar soluções e programas de redução de impacto ambiental, propondo a implantação de um crematório na Necrópole Ecumênica Vertical Universal. Aborda o tratamento que deve ser dispensado aos corpos, a fim de evitar que estes contaminem o solo e a água. 0 relatório expõe a relevância do respeito aos princípios éticos e culturais de cada grupo em relação ao preparo do corpo antes do sepultamento. Alguns grupos, por exemplo, desaprovam a cremação. Desse modo, o estudo defende uma elucubração ética quanto ao preparo e ao destino do corpo morto. Por se tratar de uma análise do grupo curitibano - que não apresenta maiores empecilhos, valoriza-se a cremação enquanto recurso 
econômico e ambiental mais adequado. Tais argumentos servem, assim, como justificativa para a instauração de um crematório no interior do Cemitério Ecumênico Vertical de Curitiba. Vale ressaltar que a Igreja Espiritualista Universal é a proprietária da necrópole vertical da cidade. Em termos estratégicos, cabe a observação de que a expressão "ecumênico" instaura, de antemão, uma equidade religiosa favorável à criação de um espaço neutro, propício portanto ao abrigo de quaisquer religiões e, consequentemente distante de símbolos religiosos. 0 símbolo de Cristo crucificado, por exemplo, não abrange nem contempla a totalidade religiosa. Cria-se, dessa forma um distanciamento físico do símbolo, que lentamente converge para um distanciamento também espiritual, de modo a comprometer a memória de uma dada coletividade. Trata-se, logo, de um espaço não identitário.

Já os cemitérios tradicionais, em sua maioria, costumam carregar nomes de santos católicos, mas essa tradição tem cada vez menos caráter de realidade. Como mostra o caso esboçado acima, o cemitério vertical de Curitiba é designado de forma pragmática, sem referências a entidades sagradas. Em seu interior, o uso de monumentos é reduzido de forma radical. É válido lembrar que o sepultamento do corpo em terra remete às ideias de ressureição e de descanso provisório para o cristianismo.

É sabido que, no interior do cemitério vertical de Curitiba, existem espaços destinados à oração. Um é o oratório, o outro a capela para meditação privativa. Esses espaços, apesar da aura religiosa, apresentam apenas resquícios longínquos da sacralização da morte.

O segundo trabalho analisado foi desenvolvido por Kátia Maria Santos de Andrade Pizzol (2010), para o Programa de Mestrado em Desenvolvimento e Meio Ambiente. A temática da dissertação gira em torno da paisagem dos cemitérios urbanos, mais especificamente os cemitérios localizados em João Pessoa/PB. De acordo com o estudo, a representação arquitetônica dos túmulos reflete a sociedade, de modo que a arte funerária é concebida como forma de eternização da presença de um homem e/ou de grupos sociais que obtiveram destaque em determinado período histórico - ideia também defendida por Rodrigues (1983).

0 trabalho de Pizzol é consonante com as ideias de Foucault (1988). Este explica que o espaço do cemitério assemelha-se ao espaço urbano: no final do século XIX, a morfologia urbana é refletida no cemitério, tornando-se nítida a construção de ruas, quadras e lotes formados por túmulos. Assemelham-se, desse modo, também (o cemitério e a cidade) por suas complicações e desenlaces. As metrópoles atuais vivenciam a problemática da falta de espaço físico, impasse solucionado com a verticalização de suas estruturas. A construção arquitetônica vertical - recurso de racionalização e otimização espacial - torna-se, assim, traço significativo da consti- 
tuição urbana atual, o que abarca, inclusive, os cemitérios. Pode-se dizer, então, que, na contemporaneidade, os cemitérios verticais também apresentam em seu interior um reflexo da organização urbana: valoriza-se uma arquitetura geométrica, limpa, reta, sem o uso de adornos e traços curvilíneos. A tese vai ao encontro dos apontamentos de Elias (1982), que destaca os cemitérios atuais como espaços organizados e fundados exclusivamente na racionalização, ou seja, na eficiência quanto à forma de utilizar o espaço físico da cidade, de modo a atender a demanda populacional por mais lugar.

As covas perpétuas geram o problema da falta de espaço, uma vez que impedem a rotatividade do uso do solo, reduzindo a possibilidade de áreas destinadas a novos sepultamentos. Soma-se a isso o fato de que, para as famílias, a hipótese de sepultar vários corpos numa mesma cova soa desagradável e até desrespeitosa (outro traço longínquo da ideia de sacralização do corpo morto), dada a impossibilidade de identificação do corpo e, consequentemente, do reconhecimento da individualidade deste. Rodrigues (1983) destaca que esse caráter de perenidade da sepultura foi atribuído e assegurado, inicialmente, pela burguesia, e perpetuado até a contemporaneidade.

Em João Pessoa, os cemitérios do tipo parque ou jardim assumem um caráter de prestígio e exclusividade. Existem apenas dois e estes são privados, demandados majoritariamente pelas classes média e alta, em razão das elevadas taxas cobradas pela manutenção das sepulturas. São ecumênicos e tratam a morte de forma singular. Uma etnografia realizada ao longo do processo de confecção da tese aponta que se trata de espaços que adotam a simplicidade: os símbolos funerários são significativamente reduzidos, e a identificação dos corpos se dá por meio de lápides padronizadas, igualmente dispostas em cada sepulcro, de maneira a atenuar - ou até mesmo suprimir - diferenças individuais e sociais, como profissão, aspectos da personalidade, méritos e conquistas. "Os lugares reservados aos mortos em uma sociedade reproduzem o mundo dos vivos, estando ambos conduzidos pela mesma lógica de organização, os cemitérios foram estendidos como um lugar de repetição simbólica do universo real" (HöFKE, 2008, p. 278).

Instaura-se, assim, um vínculo entre morte, secularização, discurso científico e racionalização do mundo. 0 "morrer" ocorre em hospitais, e não mais em casa. 0 mundo é permeado por valores racionais, pela valorização do tempo presente, pela aquisição de bens materiais. Nesse contexto, a morte desarticula os sentidos da vida moderna, esvazia os sentidos da acumulação de dinheiro, do culto ao corpo, à aparência.

0 discurso científico a que concerne essa temática é abordado por Kuhn (1962), num estudo sobre o aspecto paradigmático da ciência e a constante movimentação desse elemento, no qual ocorre a substituição de um paradigma por outro, 
verificando-se, então, as transformações do pensamento científico. Um paradigma consiste em um conjunto de valores, técnicas e crenças sustentados por uma comunidade, que tem por finalidade gerar soluções, modelos de respostas que atendam aos fatos vigentes. No momento em que fatos concretos não se enquadram nos paradigmas existentes, irrompe-se uma crise, uma anomalia, que demanda a construção de um novo paradigma.

Para Kunh, "paradigmas são as realizações científicas universalmente conhecidas, que, durante algum tempo, fornecem problemas e soluções modelares para uma comunidade praticante de uma ciência" (KunH, 1962, p. 16). Assim, a ciência, via de regra, é composta por uma determinação dos fatos significativos, pela harmonização dos fatos com a teoria e, por fim, pela articulação da teoria.

A crise paradigmática instala-se a partir da existência de anomalias, que são fatos não enquadrados nos modelos e valores já existentes. Logo, a instauração de um novo paradigma implica a substituição total ou parcial do modelo anteriormente consolidado, gerando significativas alterações nas concepções de mundo.

Aplicadas as observações de Kunh ao contexto deste estudo, pode-se inferir que a predominância de um novo paradigma que valoriza o meio ambiente culmina numa ressignificação da morte, que, não apenas a destitui em grande medida de seu caráter sagrado, como também a coloca na condição de questão-problema no mundo contemporâneo: é um potencial agente contaminador de águas subterrâneas.

Deve-se considerar, contudo, o caráter dinâmico das mudanças paradigmáticas e de suas implicações, em constantes processo e movimento. Assim, embora o recente paradigma da sustentabilidade do meio ambiente confira um novo valor à morte, ainda vigora a possibilidade de que esse novo paradigma não condicione a morte a um processo de secularização e racionalismo exacerbado, em prejuízo dos valores religiosos.

De um ponto de vista mais pragmático, Rodrigues (1983) concebe a morte como um incômodo que deve ser, tanto quanto possível, minimizado. Partindo-se desse pressuposto, adequado seria que se cultivassem métodos mais eficazes de dissipação do corpo, métodos esses limpos, isentos do processo de decomposição, e sem quaisquer prejuízos ao meio ambiente. Os corpos não cremados deveriam, assim, ser guardados em ambientes com arquiteturas mais funcionais e menos referenciais em relação às identidades. Dessa forma, incopora-se a este artigo o desenvolvimento teórico de autores que abordam a morte em nossa sociedade em sua condição de interdito, de tabu. Sob essa óptica, a secularização funciona como artifício de distanciamento da morte e de seus ritos religiosos. 


\section{Morte ecologicamente correta: descrição e análise de treze trabalhos acadê- micos}

Destacar-se-ão aqui os pontos de cada um dos 13 trabalhos analisados, que tratam da necessidade de dar ao morto um destino adequado no sentido de não causar prejuízos ao meio ambiente (é preciso morrer de forma ecologicamente correta). Todavia, há divergências argumentativas e controvérsias quanto à defesa do cemitério vertical apresentada em cada trabalho. o que torna a análise mais complexa. 0 termo "ecologicamente correto" tem, frequentemente, seu sentido ampliado ao ponto da generalização, visto que não há uma unidade de pensamento que o defina. 0 modo como esse discurso vem sendo construído será também descrito e, posteriormente, analisado, bem como o impacto dos argumentos da poluição do solo e da falta de espaço sobre a opção pela verticalização do espaço funerário e pela cremação.

0 terceiro estudo foi um trabalho final apresentado ao curso de Especialização em Gestão Ambiental da Universidade Franciscana - UNIFRA (AlCÂNTARA et al., 2010), que aborda os recursos naturais contaminados por necrópoles. 0 solo e os mananciais hídricos são afetados por micro-organismos que surgem da decomposição dos corpos. No início do trabalho, o cemitério é conceitualizado como um lugar para "depositar corpos", um espaço para enterramento. Essa concepção vai de encontro ao conceito de cemitério, do grego Koimetérion, que caracteriza um lugar para que os mortos possam dormir. Dessa forma, os cristãos subentendem que aqueles que dormem poderão acordar, sair do estado de letargia gerado pelo sono. No texto acadêmico em questão, não se estabelecem relações entre o cemitério e conceitos religiosos que tratam a morte como algo provisório, como um estado de torpor. Isso parece ser uma constante nos 13 textos analisados, e apresenta-se o cemitério enquanto lugar de neutralidade, sem influências de uma "vida do além mundo".

A necrópole gera gás metano, necrochorume e agentes patogênicos. Devido a isso, cemitérios públicos e privados são fiscalizados e, frequentemente, multados pelos órgãos responsáveis pela proteção do meio ambiente. No Brasil, as principais doenças de transmissão hídrica são a hepatite, a leptospirose, a febre tifoide, a cólera e a poliomielite. Assim, a água da chuva que entra em contato com o corpo decomposto pode ser uma das fontes de proliferação das doenças supracitadas. Nesse trabalho, o "ecologicamente correto" trata do controle de todos os cemitérios. Não aponta a verticalização como resposta aos problemas ambientais e não condena a estruturação dos cemitérios tradicionais.

De volta ao caso anterior, o Relatório de Impacto Ambiental-RIMA aborda o cemitério tradicional e suas desvantagens devido à contaminação dos lençóis freáticos pelo necrochorume. Sob a ótica desse discurso, percebe-se que a necrópole 
tradicional sofre uma espécie de depreciação por constituir vetor de agentes poluentes. Assim, é preciso construir um espaço fúnebre que não cause impactos ambientais negativos. Junta-se a isso outro dado: em Curitiba (de acordo com o mesmo relatório) a falta de espaço nos cemitérios públicos chega ao ponto da necessidade de fila de espera para a compra de terrenos. Nesse contexto, o Relatório incentiva a construção e o uso de crematórios, a fim de garantir segurança, conforto e proteção ao meio ambiente.

Nesse ponto, o termo "ecologicamente correto" ganha outra acepção - quando comparado à proposta de controle e fiscalização dos cemitérios tradicionais - e relaciona-se mais especificamente à cremação (apontada pelo RIMA como melhor medida de proteção ao meio ambiente). Além do já proposto cemitério vertical, a cremação apresenta-se agora enquanto destino alternativo para os mortos.

De acordo com o relatório, a incineração evita a contaminação do solo e de águas subterrâneas. Segundo os próprios relatores, tal medida gera outro tipo de contaminação, a poluição por gases emitidos durante o processo crematório, mas estes são regulados por meio de um sistema de controle de poluição. Assim, o RIMA enfatiza as vantagens desse sistema, a exemplo da ausência de ruídos para trabalhadores e para a população que reside nas proximidades. 0 preço também é acessível às camadas populares. 0 relatório prossegue com a ideia de que a propagação de $\mathrm{CO}^{2}$ é irrisória. A emissão de gases deverá ser fiscalizada, e relatórios, constantemente apresentados ao órgão de proteção ambiental. Essa é a argumentação encontrada no RIMA.

Em suma, a instalação do crematório não deverá alterarar a rotina dos moradores da região. A construção não ocasionará impactos visuais, já que será anexada ao cemitério vertical já existente. Verifica-se, assim, a busca por uma paisagem agradável aos moradores, o que inclui a criação de um crematório que não evidencie sua função mortuária, de modo a evitar também a desvalorização imobiliária (que costuma acontecer devido ao receio dos moradores de que o crematório possa dissipar restos mortais na atmosfera). 0 relatório enfatiza que isso se trata de uma crença; que o crematório e o cemitério vertical são favoráveis ao desenvolvimento de uma urbanização planejada. Observa-se que esse discurso científico desconsidera e desqualifica o discurso popular, enquadrando-o como uma espécie de devaneio, e inferiorizando o entendimento dos moradores da região em que o crematório deverá ser instalado.

O quarto estudo consiste no artigo do geólogo Walter Malaguti Filho (2008). Esse trabalho apresenta uma considerável diferença em relação aos anteriores, pois trata da recuperação de áreas de cemitérios que não foram planejados e que causaram - e ainda causam - danos ambientais, a exemplo do escoamento de necrochoru- 
me, que coloca em risco a saúde dos trabalhadores do cemitério e das pessoas que moram nas proximidades. Aborda, desse modo, a recuperação das necrópoles tradicionais, em vez da extinção desse espaço, propondo a estas um prazo de dois anos para que se adequem às regras do CONAMA, recuperem as áreas contaminadas, e indenizem as vítimas. As resoluções CONAMA n. 335 e n. 368 visam a garantir uma decomposição normal do cadáver, sem afetar de forma nociva as águas subterrâneas.

O quinto texto analisado discorre sobre a ausência de legislação para a construção de cemitérios em Sergipe, e foi elaborado por Ramos (2011). De acordo com o presidente da Administração Estadual do Meio Ambiente, existe somente um cemitério em Sergipe que atende aos parâmetros legais e segue sem danificar o meio ambiente. É um cemitério do tipo parque, e se localiza em Aracaju. A imprensa constantemente expõe a precária situação dos cemitérios: casos de superlotação que geram a construção de cemitérios clandestinos, prejudicando o meio ambiente, a saúde pública e a integridade física e moral das pessoas. Mais uma vez, verifica-se o argumento da falta de espaço a serviço da ideia de inadequação ambiental e civil dos cemitérios tradicionais.

Como os cemitérios desta região são antigos, torna-se difícil realizar as modificações necessárias para que a poluição do meio ambiente cesse, como propõe o estudo de Ramos. As famílias detentoras de mausoléus e túmulos recusam a destruição e posterior reconstrução das necrópoles em outro território que esteja de acordo com o processo de licenciamento ambiental. As famílias asseguram a manutenção de sua memória por meio dos monumentos funerários. Assim, Ramos destaca a quase inexistente prática da cremação em Sergipe, e os possíveis prejuízos decorrentes dessa medida, a exemplo da liberação de gases poluentes.

0 sexto trabalho, da autoria de Rodrigues (2002), consiste numa monografia para o curso de Arquitetura e Urbanismo da Universidade Federal do Rio Grande do Norte (UFRN), e consta de um anteprojeto de construção de um cemitério vertical e de um crematório, que visam atender a diferentes religiões, a partir de um espaço universalizado e múltiplo. O nome proposto para a obra no projeto é "In Memorian", e dá ênfase à continuação dos ritos de lembrança aos mortos. Observa-se, nesse ponto, uma incongruência: o nome "In Memorian" vai de encontro ao caráter ecumênico proposto, uma vez que a preservação da memória está diretamente vinculada aos símbolos, nesse caso, ícones indicadores das dessemelhanças de cada crença/religião. Entende-se, então, que a questão deve ser melhor avaliada e problematizada.

Quanto à cremação, nota-se que (a)tende aos ritos da Igreja Católica, atualmente favorável ao ato, desde que ocorra uma cerimônia de acordo com as orientações religiosas. Ao final da cremação, as cinzas são guardadas em urnas cinerárias 
que apresentam ornamentos diversos que remetem à sacralização da morte e possibilitam a homenagem póstuma, embora não tão complexa quanto a que se verifica nos ritos dos demais monumentos funerários. Esse proceso de desritualização da morte pode ser compreendido como secularização, em que símbolos religiosos presentes no ritual são progresivamente suprimidos e afastados.

O sétimo estudo, de Silva (2013), consiste num trabalho apresentado ao curso de Arquitetura e Urbanismo, do Centro Universitário do Leste de Minas Gerais - Unileste-MG, em Ipatinga/MG. Aborda a sustentabilidade alcançada por meio da implantação dos cemitérios verticais. Associa a sustentabilidade ao estilo aquitetônico de tais construções, semelhantes a prédios, sem drásticas discrepâncias das moradias comuns.

A oitava análise da pesquisa bibliográfica volta-se aos estudos de Pacheco (1986). Este evoca as problemáticas psicológicas e físicas que incidem sobre os entornos dos cemitérios. Situações como medo da morte e superstições criam um desejo de afastamento do espaço destinado aos mortos, o que impele as pessoas buscarem estabelecer suas moradias longe dos túmulos. Entretanto, o estudo destaca que os mais significativos impactos são os de ordem física. Entede-se, neste ponto, a necessidade de questionar: um impacto é, de fato, mais significativo que outro? Ambos merecem ser analisados de forma dialógica.

Pacheco (1986) expõe que, acerca dos métodos de prevenção da contaminação, destacam-se a profundidade do nível da água, a capacidade de retenção do solo e a topografia, ou seja, a baixa declividade é recomendada. Em outras palavras, o estudo mostra que é possível manter o cemitério do tipo tradicional sem afetar o meio ambiente. Dessa forma, o cemitério vertical se configura como uma das alternativas arquitetônicas que pode evitar a contaminação do solo e da água, excluindo-se a ideia de que consiste na única solução viável e adequada.

A nona análise ocupa-se do trabalho da geógrafa Bacigalupo, que versa sobre o cemitério Nossa Senhora de Fátima, localizado em Duque de Caxias/RJ. A investigação ocorreu no interior da necrópole e na comunidade próxima ao cemitério. Nessa pesquisa, realizou-se um trabalho de campo, com entrevistas aos moradores - primeiro trabalho analisado com caráter de valorização das pessoas e de seus discursos. 0 estudo revelou que, devido ao solo argiloso e ao alto índice pluviométrico da região, o processo de decomposição é prolongado, o que dificulta a reutilização dos espaços de sepultura.

0 décimo texto é um artigo elaborado por um grupo de graduandas em Ciências Biológicas de São Paulo, da Universidade Nove de Julho/Departamento da Saúde. As autoras abordam a questão dos resíduos de cemitério - a crescente relevância 
dessa problemática e as possíveis ações para solucionar tal quadro. 0 necrochorume ganha destaque e é classificado como o principal resíduo poluente originado pelo cemitério. A fim de solucionar os transtornos à saúde pública causados pelo efluente, incentiva-se a construção de necrópoles verticais e de crematórios. A resolução CONAMA n. 335, de 28 de maio de 2003, atua de forma precária, uma vez que faz-se necessária uma fiscalização adequada dos cemitérios para que a lei vigore também na prática (GAGLIANo et al., 2011).

Uma breve análise do processo de transformação da arquitetura dos cemitérios ao longo dos anos mostra que, quando entrou em voga a ideia de construir os cemitérios longe das cidades, ainda não haviam sido dimensionados os riscos e danos que o sepultamento realizado diretamente no solo poderiam causar à saúde e ao meio ambiente. Assim, usavam-se terrenos de menor valor financeiro para a construção dos cemitérios, desprezando-se quaisquer estudos geológicos ou hídricos. Já no século XX, o estudo desses espaços ganhou também dimensão ambiental, não apenas em área específica mas em diversos nichos científicos. No Brasil, destaca-se o trabalho desenvolvido por Alberto Pacheco em 1986, que elabora de forma pioneira uma investigação sobre os riscos ambientas derivados da falta de planejamento no processo de instalação das necrópoles.

0 geólogo Leziro Marques (2010) pesquisou 600 cemitérios brasileiros e, como resultado, concluiu que $75 \%$ desses espaços poluem o meio ambiente, principalmente como necrochorume. Ademais, os vasos dos túmulos acumulam água parada, potencializando a proliferação do Aedes Aegypti e, consequentemente, aumentando os casos de dengue e de febre amarela.

0 décimo texto analisado trata das vantagens e desvantagens da cremação. Um dos benefícios dessa medida consiste na destruição dos organismos patogênicos no processo de incineração do corpo. A cremação, por outro lado, evoca polêmica quanto a determinadas crenças e valores religiosos e culturais que devem ser considerados ao se proceder com os sepultamentos.

No que tange o cemitério vertical, é evidente que sua arquitetura sui generis apresenta uma solução favorável ao crescimento populacional e à demanda por espaço. Além disso, é ecologicamente correto. Todavia, esse tipo de cemitério exige demasiado planejamento no que diz respeito ao destino dos efluentes gasosos, de modo a garantir o caráter higiênico da área de sepultamentos. De outro modo, o mau cheiro tornaria inviável a livre circulação de pessoas no local de engavetamento dos corpos.

Em outros termos, a proposta do cemitério vertical sana os problemas ambientais que concernem aos danos causados pelo necrochorume, mas ignora a pro- 
blemática da poluição atmosférica causada pela cremação e pela emissão de gases oriunda de outros processos. 0 que pouco se destaca, entretanto, é a solução encontrada numa reelaboração dos cemitérios tradicionais (onde o corpo é sepultado diretamente no solo) com base em estudos ambientais consistentes e ficalizações efetivas e adequadas. Mesmo a questão da falta de espaço pode ser amenizada com sepulturas rotativas. Portanto, percebe-se que a preocupação do discurso técnicocientífico não se volta à melhoria dos cemitérios tradicionais, mas à construção de novos cemitérios que apresentem duas caracterísiticas relevantes: a conservação do meio ambiente, e a criação de espaços em que a morte seja concebida de forma laica. Essa pretendida neutralidade, todavia, não existe, já que todo espaço comunica uma ideia. Assim, mesmo através do não dito, os símbolos - e toda a complexa gama de significados, contextos e pensamentos a que eles remetem - permeiam o conceito de espaço fúnebre, de modo que a busca pela construção de cemitérios que tentem calar essa tradição implica um desejo de afastamento da própria ideia da morte enquanto fato.

0 décimo primeiro texto acadêmico usado como referência bibliográfica é uma Tese de Doutorado, de natureza majoritariamente técnica, da área de Recursos Minerais e Hidrogeologia. Foi elaborada em 2001 por Bolivar Antunes Matos. A tese avalia a incidência e o transporte de microorganismos no aquífero freático localizado no cemitério de Vila Nova Cachoeirinha - SP. 0 autor conclui que a contaminação das águas subterrâneas ocorre principalmente devido às sepulturas mais recentes, com menos de um ano de existência, e com profundidades que se aproximam dos lençóis freáticos. As possíveis soluções para reverter esse quadro são a elaboração de projetos para a implantação de cemitérios que cumpram as exigências das prefeituras e órgãos ambientais; a elaboração de uma legislação nacional que regulamente a instalação dos cemitérios de acordo com os efetivos impactos ambientais e salutares causados por esses espaços; e o enquadramento dos cemitérios na categoria de potencial fonte de contaminação das águas subterrâneas.

0 trabalho analisado em seguida expõe de que forma o planejamento da capacidade do cemitério pode ser aplicado à gestão de cemitérios municipais. 0 autor, Luciano Sacramento de Paula, realizou um estudo de caso do Cemitério Municipal de Resende, apresentando um conceito de Desenvolvimento Sustentável, que atende as demandas do presente sem prejudicar as gerações futuras.

Por fim, o décimo terceiro estudo foi desenvolvido por uma bióloga. Leite (2009) é especialista em Ecologia e Intervenções pelo Centro Universitário Jorge Amado (UNIJORGE). A temática aborda os agentes patogênicos contaminadores de três poços que se localizam nas proximidades do cemitério da comunidade de San- 
tana, em Ilha da Maré, Salvador/BA. Rumores de que o cemitério contaminava as águas marinhas alarmaram os moradores da região, que têm a pesca como principal atividade econômica. Os receios da comunidade cresceram, e cogita-se, inclusive, a interdição do espaço.

\section{Não há espaço para morrer nesta cidade?}

O costume de sepultamento em túmulos se configura como prática tradicional da sociedade, e relaciona-se a aspectos religiosos e culturais. A modificação do cemitério implica a modificação de ritos de uma coletividade. 0 túmulo é um lugar ritualístico, especialmente no Dia de Finados. Na realidade, não há espaço para que se mencione a morte e os mortos. Os finados perdem seu lugar na cidade e na memória dos vivos, assim, são compulsoriamente olvidados e apagados. Autores da Sociologia, da História e de outras áreas do conhecimento, como José Carlos Rodrigues (1983), Mauro Koury (2001), Ariès (1977), Le Goff (1990) e Antônio Motta (2010), debruçados sobre o espaço reservado à morte na sociedade, convergem harmonicamente para essa ideia. Todos defendem que o processo de apagamento da memória dos mortos envolve diversas questões de nossa sociedade, uma das quais é elencada neste artigo, uma vez que atua de forma intensa e contundente sobre esse processo de afastamento e esquecimento verificado ao longo da história: o enfraquecimento de símbolos mortuários que sustentam as mémorias dos grupos.

0 problema da falta de espaço nos cemitérios apresentou-se como um dos principais incentivadores à proposta de modificação drástica da necrópole e da relação com os mortos, baseada em duas medidas: a cremação dos corpos e a verticalização dos cemitérios. Mas sabe-se que uma terceira proposta - a da rotatividade das sepulturas - pode resolver parcialmente essa problemática, visto que se manteriam enterrados apenas os corpos em estágio de decomposição. Após essa fase, os ossos seriam retirados e encaminhados ao ossuário (estrutura verticalizada que se encontra no interior do cemitério), fazendo cessar, assim, a construção de novas sepulturas perpétuas na necrópole tradicional.

A ideia do crescimento populacional que, teoricamente, leva à falta de espaço nos cemitérios tradicionais também merece ser problematizada e melhor avaliada. Essa tese ganha contraposição em estudos que indicam que a população brasileira apresenta reduzido índice de crescimento.

A pirâmide etária brasileira se configura de forma em que os números de idosos seja crescente e o número de nascimentos se mostre reduzido. Os avanços da medicina também contribuem para a longevidade: o aumento da expectativa de vida é significativo. 0 pesquisador Gabriel Borges, do IBGE, defende que, até 2042, esse 
crescimento será reduzido, e que, a partir dessa data o índice populacional não deverá sofrer aumentos. Deve-se, claro, considerar que o crescimento populacional incide de forma mais contundente no espaço urbano, mas, mesmo nas grandes cidades, as taxas de fecundidade e de óbito têm se reduzido. Ainda segundo o IBGE, em 2013, a taxa de fecundidade estava abaixo de 1,8, enquanto a taxa bruta de mortalidade, de 2000 a 2013 , manteve-se constante em 6.

São inúmeras e evidentes as incongruências observadas entre os dados apontados nos 13 trabalhos analisados e as informações disponibilizadas pelo Instituto Brasileiro de Geografia e Estatística. Enquanto os estudos examinados na revisão bibliográfica baseiam-se na ideia de que o número de mortos cresce e o número enquanto descresce o movimento populacional, o IBGE aponta para uma estabilidade populacional em termos de natalidade, longevidade e, consequentemente, de mortalidade. Não há um diálogo coerente entre as fontes. Cabe ressaltar, ainda, que o instituto não é citado em nenhum dos 13 estudos acadêmicos analisados.

Portanto, a problemática da falta de espaço nos cemitérios, atrelada a uma crescente demanda pelo mesmo não cabe enquanto justificativa para a criação de necrópoles verticais e de crematórios, quando confrontada com os dados apresentados pelo IBGE. Se levada em consideração a legitimidade das informações disponibilizadas pelo órgão, o crescimento populacional e a alta ocupação dos espaços dos cemitérios não podem servir de argumento-base para a proposta de extinção das necrópoles tradicionais. Por outro lado, o destaque dado a essa problemática por parte da maioria dos trabalhos acadêmicos científicos verificados pode indicar uma necessidade de se confrontarem mais diretamente as informações fornecidas pelo IBGE, de modo a rever determinadas demandas populacionais no processo de coleta dos dados. De qualquer modo, essa disparidade de informações permite inferir que outras variáveis atuam no incentivo ou não à proposta de verticalização dos cemitérios e que estas excedem o concernente a este estudo.

\section{Considerações Finais}

Os estudos analisados fundamentam-se em aspectos biológicos, químicos e físicos. A cremação do corpo e seus impactos psicológicos aos familiares e entes próximos, a ausência de símbolos religiosos, a nova construção da memória ou o aniquilamento dos ritos em memoração aos mortos não são questões exploradas nesses trabalhos. 0 foco recai quase que exclusivamente sobre os impactos ambientais e as soluções oferecidas pela proposta de verticalização dos cemitérios, a fim de manter a saúde dos vivos, os solos e águas subterrâneas a salvo, e os espaços aos futuros mortos garantidos. 
Tal solução surgere uma nova reestruturação espacial, estética e simbólica do espaço do cemitério e, para que isso se concretize, os discursos das Ciências Exatas e Naturais são tomados como base argumentativa e convenientemente postos em primeiro plano. 0 outro sentido da mudança - a necessidade de elaborar novos símbolos e ritos que contemplem a morte e os mortos - é relegado ao "segundo plano", o plano oculto do insulamento e do esquecimento. Essa nova reelaboração simbólica aparece apenas para fazer as vezes de uma consequência de banal da preservação do meio ambiente, como efeito colateral do alcance de um maior conhecimento científico sobre as formas de proliferação das doenças e dos microorganismos. Os discursos foram deliberadamente sobrepostos.

Se o meio ambiente fosse motivo exclusivo - ou, ao menos, central - que determinasse a necessidade de modificação estrutural do cemitério, o contexto atual teria como espelho o século XIX, quando os cemitérios saíram dos entornos das igrejas e foram afastados das cidades. No contexto, a questão sanitária configurava o real motivo das medidas de modificação, que incidiram basicamente sobre a localização das necrópoles, sem maiores prejuízos aos monumentos e símbolos religiosos. Dessa forma, a estética, o espaço e os símbolos do cemitério não apenas se mativeram, como ganharam significados mais ricos e complexos. Isso demonstra que a mudança de local do cemitério foi justificada por uma questão efetiva de saúde pública.

Já na contemporaneidade, os discursos ambiental e sanitário, embora válidos, escondem o principal fator de alteração do espaço funerário. Se o meio ambiente fosse de fato o ponto primário e principal da mudança, a proposta de novo cemitério atenderia à manutenção dos símbolos e túmulos que evocam a memória aos mortos e os ritos dos vivos, manteria uma configuração semelhante à anterior. Entretanto propõe-se um novo cemitério secularizado, que sequer remete à morte. Ao contrário, o cemitério se descaracteriza, adota feições laicas e pragmáticas, torna-se lugar de neutralidade e de mera funcionalidade. Poder-se-ia questionar que a defesa do meio ambiente e a mudança estética ocorrem simultaneamente, numa relação de causa e consequência, porém o caminho traçado evidencia que a preservação ambiental, além de necessária, serve de justificativa primordial para tornar plausível a construção de espaços para a morte, onde a própria morte não é, sequer, reconhecida.

Os trabalhos universitários analisados utilizam-se de um discurso impessoal, racional e pragmático, que privilegia a eficiência da arquitetura atual. 0 tema-base relaciona-se diretamente a pessoas, tanto vivas como mortas, mas a forma como os textos procedem não contempla, em definitivo, essa proposta. Isto é, o tema necessita ser abordado com a riqueza interdisciplinar que demanda. É necessário que outras áreas do conhecimento estudem a proposta dos cemitérios verticais e, mais 
do que isso, faz-se urgente uma pertinente investigação dessas justificativas. A problemática central não consiste na mudança, mas na forma como esta é justificada pelos meios científicos atuais.

Afinal, como o meio ambiente não configura de fato o motivador central da mudança, é possível que, dentro em breve, novos estudos relatem a contaminação proveniente dos cemitérios verticais e do processo de cremação. Ressalta-se aqui que os estudos ambientais são de suma importância para manter a saúde pública e a preservação do meio ambiente. Todavia, esses estudos devem se conectar a outras áreas das Ciências Humanas, e isentar-se da qualidade de causa exclusiva para a promoção de uma solução arbitrária e definitiva, estabelecida previamente ao próprio problema/causa.

A relação entre as universidades e a sociedade brasileira é dialógica e recíproca: ao mesmo tempo em que o discurso científico é um reflexo das mudanças sociais, por outro lado, é o próprio gerador e incentivador dessas mesmas mudanças. Há um comportamento social de repulsa à morte que se intensifica gradativamente. Os moradores do entorno do cemitério passaram a não olhar com agrado a paisagem de túmulos amontoados. Dessa forma, os grupos evidenciam de maneira incipiente uma mudança de atitude e uma necessidade de modificar suas representações da morte. 0 cemitério monumental não é visitado com tanta frequência, nem mesmo no Dia de Finados, e o sentido anteriormente atribuído à morte por diversos grupos e comunidades é paulatinamente esvaziado (a exemplo do comércio, que, hoje, abre regularmente num dia dedicado à memória aos mortos, dia que, outrora, era considerado sagrado).

0 discurso científico expressa também uma espécie de recusa à morte. Isso se torna evidente pela ausência de estudos que citem, ou ao menos aludam, à questão da memória, intrinseca à temática da morte. Os trabalhos aqui analisados apresentam um reflexo do social, visto que promovem a ocultação da morte por meio do cemitério vertical e da cremação. Esse mascaramento é tão radical que não se pode sequer mencionar que a mudança estética do cemitério tenciona tornar a morte algo distante e inexistente. 0 tabu da morte é intensificado sobremaneira que não é permitido falar que tentamos ocultar a morte e os mortos.

Pode-se dizer que esse mascaramento é fruto de uma permissividade moral por parte dos grupos sociais, de forma que o meio ambiente fique em primeiro plano e a memória aos mortos seja anulada, valorizando a extinção do corpo, do túmulo e seus monumentos. Ocorre que essa condescendência ainda é pouco estudada, visto que os trabalhos da área de Ciências Sociais sobre a morte são relativamente recentes, ou seja, apresentam- se com maior evidência a partir do final do século XX e 
início do século XXI, sendo tratada também por autores como Nobert Elias (1982). A bibliografia consultada para a elaboração deste artigo e que trata da morte não antecede os últimos 30 anos do século XX. Antigamente, nos séculos XIX e XX, havia uma inviolabilidade do espaço do cemitério, revestido de caráter sagrado. Este lugar não poderia ser alvo de um estudo técnico da área científica. As novas configurações sociais, no entanto, permitem o desenvolvimento desses estudos. Esse fato, por si, demonstra a progressiva dessacralização do espaço reservado aos mortos, que, cada vez mais, ganha acepções pragmáticas e funcionais, tornando-o acessível e suscetível ao discurso acadêmico-científico.

Por outro lado, esse mesmo discurso produzido na universidade é a mola propulsora das mudanças. Os relatórios técnicos são apresentados por algumas empresas que, por sua vez, serão responsáveis pela construção do novo cemitério - este classificado agora como empreendimento. Essas empresas não visam a melhorias estruturais do cemitério tradicional, com o sepultamento no solo. Tampouco têm por objetivo recuperar as áreas de águas subterrâneas contaminadas pelo necrochorume. Ademais, nos trabalhos acadêmicos, não há referências sobre o destino adequado aos corpos já sepultados em terra, que continuam a causar danos ao meio ambiente. Percebe-se que o discurso ambientalista é contraditório na medida em que não soluciona amplamente o problema. E, quando "soluciona", apresenta a necessidade de construção de novos empreendimentos, colocando em destaque o espaço mercadológico e a comercialização de bens que tornam a morte distante.

\section{Referências Bibliográficas}

AlcÂntara, L. A. (et al). (2010). “Contaminação de Recursos Naturais por Necrópoles”. Revista Disc Scientia. Série: Ciências Naturais e Tecnológicas, S. Maria,v. 11, n. 1, p. 17-28.

ARIÈs, P. (1977). História da morte no Ocidente: Da Idade Média aos nossos dias. Trad. Priscila Vianna de Siqueira. Rio de Janeiro: Francisco Alves.

BACIgALupo, R. S. Impacto do Necrochorume nas águas subterrâneas do cemitério Nossa Senhora de Fátima, Duque de Caxias- RJ. In: Congresso de Geografia- UERJ. Disponível em: http://www.eng2012.org.br/trabalhos-completos?download=1304:congresso-de-geografia\&start=2260. Acesso em: 02 de julho de 2014.

Engenharia Ambiental- ECOBR (2009). Relatório do Impacto Ambiental- RIMA. Igreja Espiritualista Universal. Crematório- Necrópole Ecumênica Vertical Universal. Curitiba.PR. Disponível em:

http://www.iap.pr.gov.br/arquivos/File/EIA_RIMA/CREMATORIO/RIMA_Crematorio_Cemiterio_Vertical.pdf. Acesso em: 04 de julho de 2014. 
Elias, N. (1982). A solidão dos moribundos seguido de envelhecer e morrer. Rio de Janeiro/RJ: Jorge Zahar, 2001.

EsPindula, J. C. (2004). Caracterização bacteriológica e físico-química das águas do aquífero freático do cemitério da várzea- Recife. Dissertação de mestrado em Geociências. Recife, Universidade Federal de Pernambuco.

Foucault, M. (1988). Microfísica do Poder. Rio de Janeiro: Graal Edições.

Gagliano, J. (et al). (2011). Resíduos de Cemitérios: Um problema emergente. In: XV Encontro Latino Americano de Iniciação Científica e XI Encontro Latino Americano de Pós- Graduação- Universidade do Vale do Paraíba.

HöFKe, T. F. (2008). Paisagem do Silêncio: Reflexões sobre o simbolismo na arte funerária. In:TERRA C. G.; ANDRADE, R.O. (Org.). Coleção Paisagens Culturais. Rio de Janeiro: Universidade Federal do Rio de Janeiro: Escola de Belas Artes, 2008. p. 276288.

Instituto Brasileiro de Geografia e Estatística- IBGE. (2013). Diretoria de Pesquisas, Coordenação de População e Indicadores Sociais, Projeção da População do Brasil por Sexo e Idade para o Período 1980-2050 - Revisão 2008. Taxa de Fecundidade Total - Brasil - 2000 a 2013. Disponível em: http://brasilemsintese.ibge.gov. br/populacao/taxas-de-fecundidade-total. Acesso em: julho de 2014.

Instituto Brasileiro de Geografia e Estatística- IBGE. (2013). Diretoria de Pesquisas, Coordenação de População e Indicadores Sociais, Projeção da População do Brasil por Sexo e Idade para o Período 1980-2050 - Revisão 2008. Taxa Bruta de Mortalidade por mil habitantes - Brasil - 2000 a 2013. Disponível em: http://brasilemsintese.ibge.gov.br/populacao/taxas-brutas-de-mortalidade Acesso em: julho de 2014.

KouRY, M. G. P. (2001). "Você fotografa os seus mortos?" In.: KOURY, Mauro (org.) Imagem e Memória: ensaios em Antropologia Visual. Rio de Janeiro: Garamond. p. 51-94.

LE Goff, J. (1990). História e Memória. Tradução Bernardo Leitão. 353p. Campinas, SP: Editora da UNICAMP, (Coleção Repertórios).

LEITE, E. B. (2009). "Análise físico-química e bacteriológica da água de poços localizados próximo ao cemitério da comunidade Santana, Ilha de Maré, Salvador-BA". Candombá- Revista Virtual, v.5, n.2, p. 132-148.

Malagutti Filho, W. (2008). "Cemitérios como áreas potencialmente contaminadas". Revista Brasileira de Ciências Ambientais, n.9, UNESP, p. 26-36.

Matos, B.A. (2001). Avaliação da Ocorrência e do Transporte de Microrganismos no Aqüífero Freático do Cemitério de Vila Nova Cachoeirinha, Município de São Paulo. São 
Paulo, 172 p. Tese (Doutorado). Instituto de Geociências, Universidade de São Paulo. Pós-graduação.

Moтta, A. (2010). "Estilos mortuários e modos de sociabilidade em cemitérios Brasileiros oitocentistas". Universidade Federal de Pernambuco-Brasil. Horizontes. Antropológicos, vol. 16 n.33, Porto Alegre 2010.

PACHeco, A. (1986) "Os cemitérios como risco potencial para as águas de abastecimento". Revista Sistema de Planejamento para a Administração Metropolitana. Ano 4, n. 17, 1986.

Paula, L. S. Gestão do Planejamento da Capacidade em Cemitérios Municipais. Disponível em: http://www.aedb.br/seget/artigos05/332_Planecapacidade.pdf. Acesso em: 28 de julho de 2014.

Pizzol, K. M. S. A. (2010). "Reflexões e descobertas na paisagem de cemitérios urbanos: Um olhar entre muros em cemitérios de João Pessoa-PB”. Revista online- Caminhos da Geografia, v.12, n.37, p.185-200. Uberlândia.

Ramos, L. G. O. (2011). "A questão no necrochorume em Sergipe”. Disponível em: http://jus.com.br/artigos/20617/a-questao-do-necrochorume-em-sergipe Acesso em: junho de 2014.

Reis Sobrinho, B. M. (2002). Cemitério e Meio Ambiente. Monografia, Universidade Católica do Salvador. Disponível em: http://www.revistaea.org/artigo.php?idartigo=107\&class=21 Acesso em: junho 2014 .

Rodrigues, A. (2002). In Memorian: Cemitério Vertical e crematório. Monografia, Natal, Universidade Federal do Rio Grande do Norte.

Rodrigues, J. C. (1983). Tabu da Morte. Rio de Janeiro: Editora Achiamé, 296 p.

SiLva, N. S. (2013). Cemitério Vertical Sustentável. Monografia, Centro Universitário do Leste de Minas Gerais-UnilesteMG. Disponível em:

http://issuu.com/nolianasousa/docs/para postar no blog Acesso em: junho de 2014.

Recebido em Agosto/ 2014

Aprovado em Abril/ 2015 